\title{
The Impact of Rising Oil Prices on the Transport Sector
}

\begin{abstract}
Oil is the dominant motorized transportation fuel used in most countries, including Australia. Many other oil-derived products and services are important to the functioning of the Australian economy. It makes sense, then, that this issue of Australian Planner focuses on the risks associated with scarce and/or expensive oil. This paper provides background information about oil consumption in Australia, and reviews the available information on price elasticities for the major oil end-uses. Based on this review, the impact of higher oil prices is assessed, and short and long run policy options are discussed. Reducing fuel used for private motoring, and preparing emergency adaptation plans to cope with sudden oil price spikes are identified as the major areas for planners to focus on.
\end{abstract}

\section{Introduction}

This paper has four purposes: to give the reader a clearer understanding of how oil is currently used in Australia; to provide details of the historical trends that got us to where we are today; to see where those trends would take us under business as usual; and finally, to use this information to inform us on how planners may help prepare for dramatically higher oil prices. In recognition of the fact that planning practitioners and policy makers operate under practical and political constraints, this paper deliberately focuses on those policies that represent small to moderate deviations from 'business as usual'. This paper does not, for example, discuss laudable end-goals such as decarbonizing our economy, or drastically reorganizing our cities, because planners have limited influence over economic policy, and because less ambitious policies such as congestion charging are still contentious and difficult to put in place. Other papers in this special edition cover more creative diversions from 'business as usual'. See, for example, the papers by Mees and Stone, and Newman and Wight, in this volume.

\section{Oil: not just another energy source}

It is natural at first to think of oil as just one energy source that is interchangeable with the many others that make up our total energy consumption. The total energy consumed in the form of oil makes up 33.6\% of our total primary energy use (ABARE 2009, page 6), and it is easy enough to remain optimistic that, in the face of high oil prices, oil could be substituted with some other more abundant fuel, such as coal or natural gas. But to look at oil in this way is a mistake. A shortage of oil will have important consequences not because there are no other energy sources, but because oil use is concentrated in the transport sector, where it is difficult to find substitute liquid fuels, or to transition quickly to alternate non-liquid fuel technology. This was put succinctly in the influential Hirsch report:

Oil peaking will create a severe liquid fuels problem for the transportation sector, not an 'energy crisis' in the usual sense that the term has been used. (Hirsch et al., 2005, page 5)

Figure 1 shows that while transport does represent a significant proportion (24\%) of total Australian energy consumption, it is less important than either electricity generation or manufacturing in terms of energy use. 


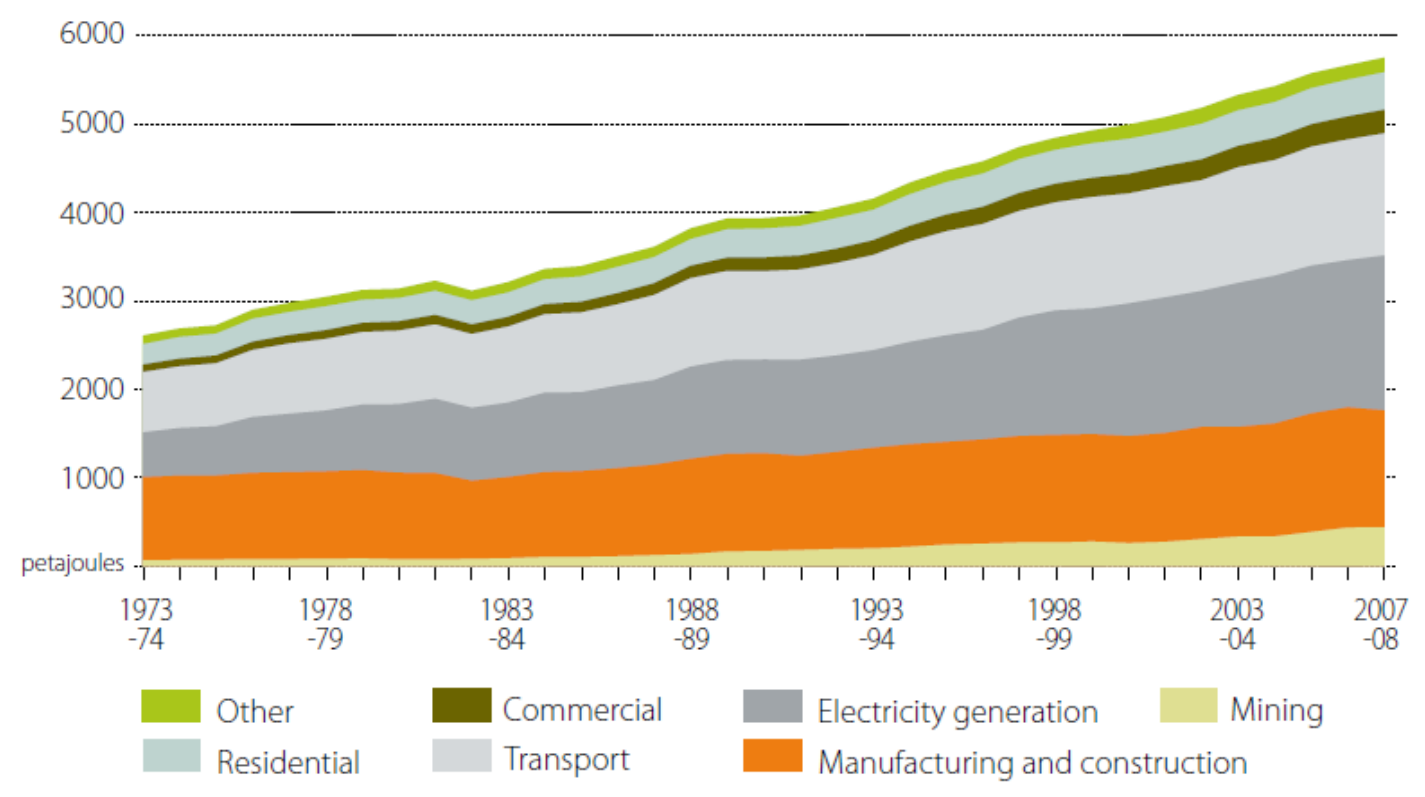

Figure 1. Energy use in Australia by sector. Source: ABARE (2009, page 4).

\section{Oil use in Australia}

Oil is responsible for around a third of total primary energy consumption in Australia (ABARE, 2009), but because of its energy-density and relatively high cost (compared to coal and gas), its use is concentrated in areas where other energy sources are not good substitutes. This is mostly in transport: $72 \%$ of the oil used in Australia is used for transport fuel. Even this slightly understates the importance of oil as a liquid fuel for vehicles, as oil consumed in farm and mining vehicles is accounted for separately in those sectors. Remaining uses of oil are varied, and range from fuel use in agricultural and mining machinery to the making of plastics, fertilizers, mechanical oils/lubricants, and bitumen. Figure 2 shows a coarse breakdown of oil consumption in Australia, taken from data in ABARE (2009, page 14). After transport (72\%), mining $(8.5 \%)$, chemicals/lubricants (7.1\%), and agriculture $(4.8 \%)$ account for most remaining oil consumption.

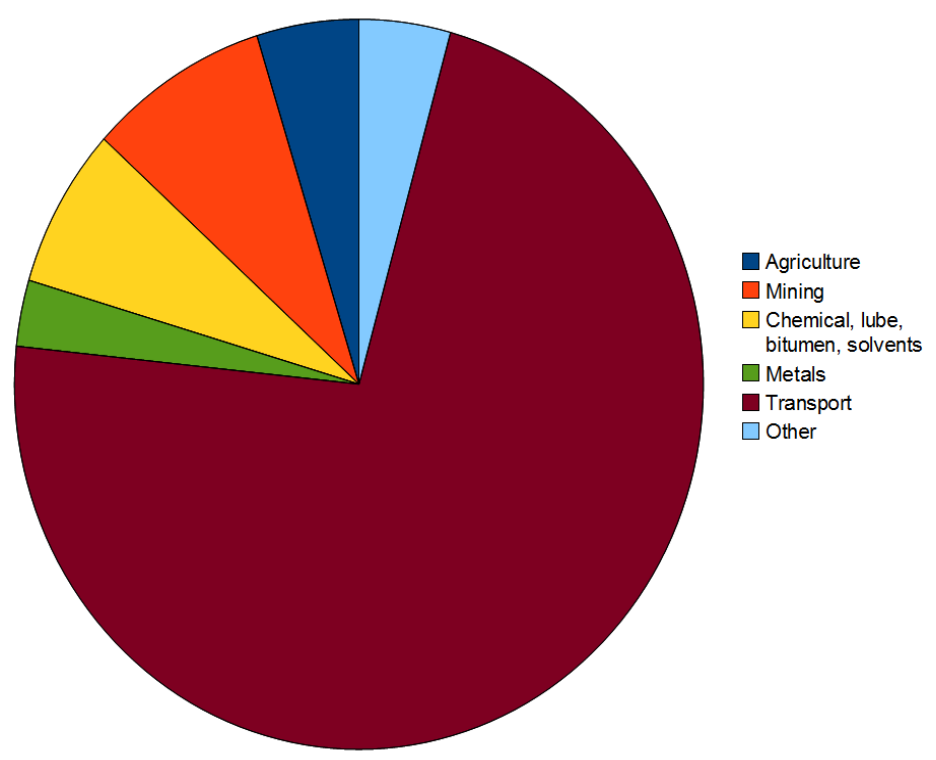

Figure 2. Breakdown of oil consumption in Australia. Data source: ABARE (2009, page 14). 
Because oil is used predominently in transport, it is useful to break transport-related use down further. Figure 3 shows a refined breakdown. Road transport (private and commercial) is responsible for $76 \%$ of transport-related oil consumption, and aviation $17 \%$, with only small amounts from rail (2\%) and water (5\%) transport.

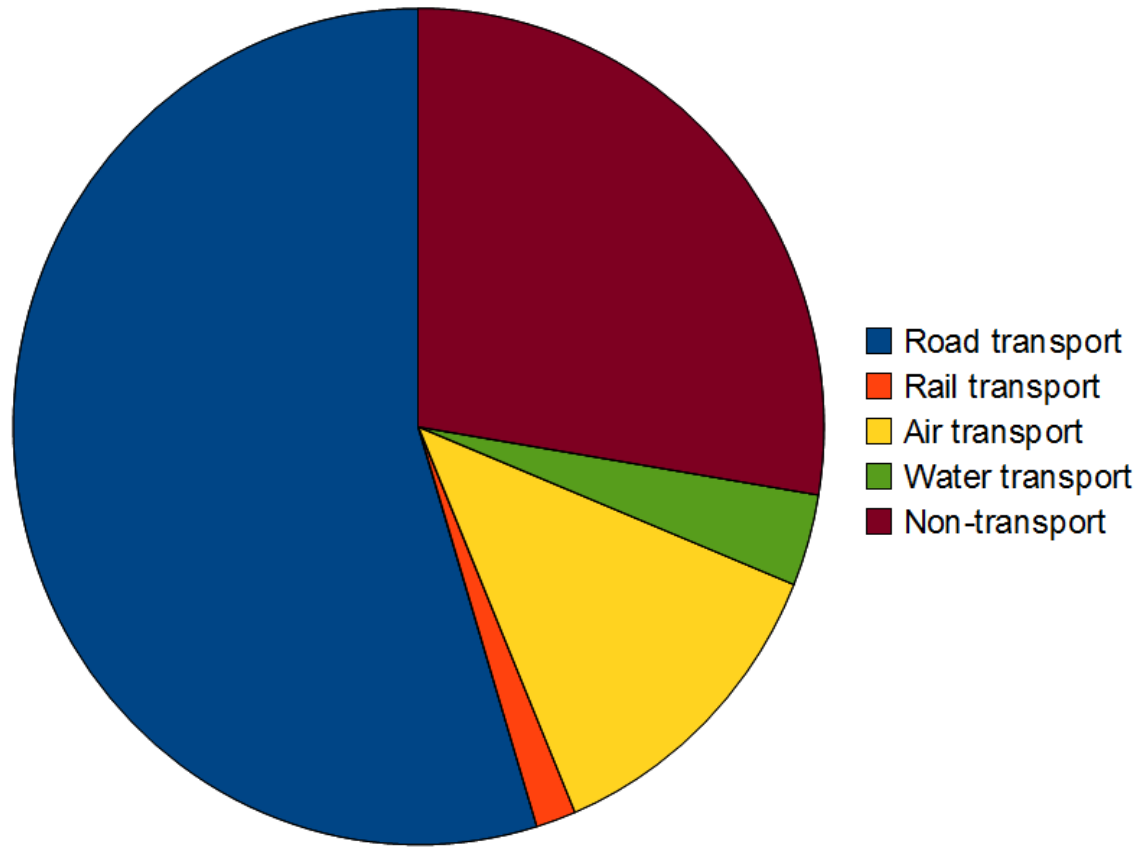

Figure 3. Oil consumption in Australia by transport end-uses. Data source: ABARE (2009, page 14).

The large 'road transport' wedge shown in Figure 3 can be broken down into its constituent parts, as shown in Figure 4.

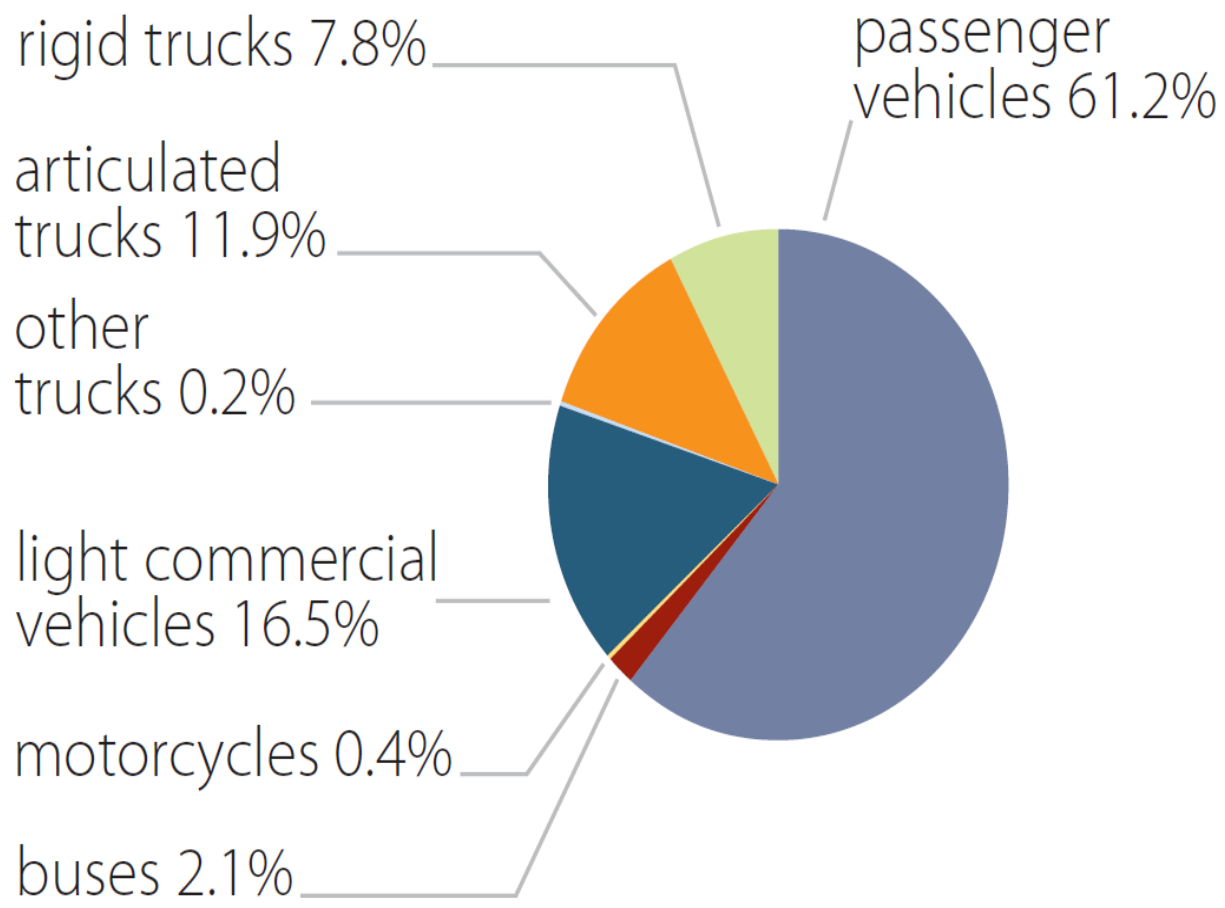

Figure 4. Road transport fuel consumption in Australia (2005-6). Reproduced from ABARE (2009, page 68). 
What does the preceding information tell us? We can calculate that private car-based personal transport is currently responsible for $\sim 35 \%$ of all oil consumption in Australia, commercial trucking $20 \%$, aviation $13 \%$, and numerous other non-transport sources account for the remaining $32 \%$. If oil were to become increasingly expensive, how could each of these sectors adjust, and over what time-period is this adjustment possible? I will consider these questions in the following section, but will concentrate on the transport sector, as the non-transport uses are too varied to be covered in any detail in this article.

\section{Important drivers of oil use in Australia}

Before examining, in Section 5, the ability of different transport sectors to adjust to high oil prices, we should understand what factors have combined to produce our current patterns of oil consumption, and what our future consumption patterns might look like under 'business as usual'. I take business as usual to mean rising real incomes, moderately priced oil (less than \$US 100 barrel, in 2010 dollars), and no great changes in transport infrastructure or policy. This section breaks Australia's oil consumption into four end-uses: car-based personal transport; commercial trucking; air travel; and other. Focussing on the first three transport end-uses, I will examine the important factors that have driven patterns of consumption, and the factors likely to be important in the future. To frame this examination, Table 1 presents historical aggregate and per-capita growth in fuel consumption for the three transport end-uses chosen.

\begin{tabular}{|l|l|l|}
\hline Sector & $\begin{array}{l}\text { Annual fuel } \\
\text { consumption growth } \\
\mathbf{( 1 9 8 7 - 2 0 0 7 )}\end{array}$ & $\begin{array}{l}\text { Per-capita fuel } \\
\text { consumption growth } \\
\mathbf{( 1 9 8 7 - 2 0 0 7 )}\end{array}$ \\
\hline Car-based personal transport & $0.75 \%$ & $-0.53 \%$ \\
\hline Commercial trucking & $3.54 \%$ & $2.20 \%$ \\
\hline Aviation & $3.97 \%$ & $2.65 \%$ \\
\hline
\end{tabular}

Table 1. Compound growth in aggregate and per-capita fuel use in Australia, 1987-2007. Source: BITRE (2009, page 153)

\section{Car-based personal transport (35\% of total oil)}

Summary: Plateauing per-capita vehicle-kilometres travelled (VKT) will allow per-capita fuel consumption to decline, but population growth will continue to increase total demand for oil.

Apart from increasing population, there are two other trends that have been responsible for steady growth in oil consumption from passenger vehicles: increasing car ownership; and a corresponding increase in per-capita VKT (due to increased access to cars and lower occupancy ratios, as well as other factors). Partly offsetting this has been a steady increase in vehicle fuel efficiency. Figures 5 and 6 show the VKT and car-ownership trends, respectively. These trends clearly cant continue forever - car ownership must surely saturate at some level approaching 1 car per adult, and VKT must plateau given that people have limited time to devote to travel. Recent Australian data suggests that per-capita VKT is approaching these upper limits (BITRE, 2009). A similar plateauing is observable in the US (Office of Highway Policy Information, 2010). Car-ownership levels currently show no obvious sign of plateauing, but such a plateau seems 
imminent given that car ownership levels are 0.54 per person (BITRE, 2009) and less than two thirds of Australia's population are aged sixteen or older (ABS, 2009a).

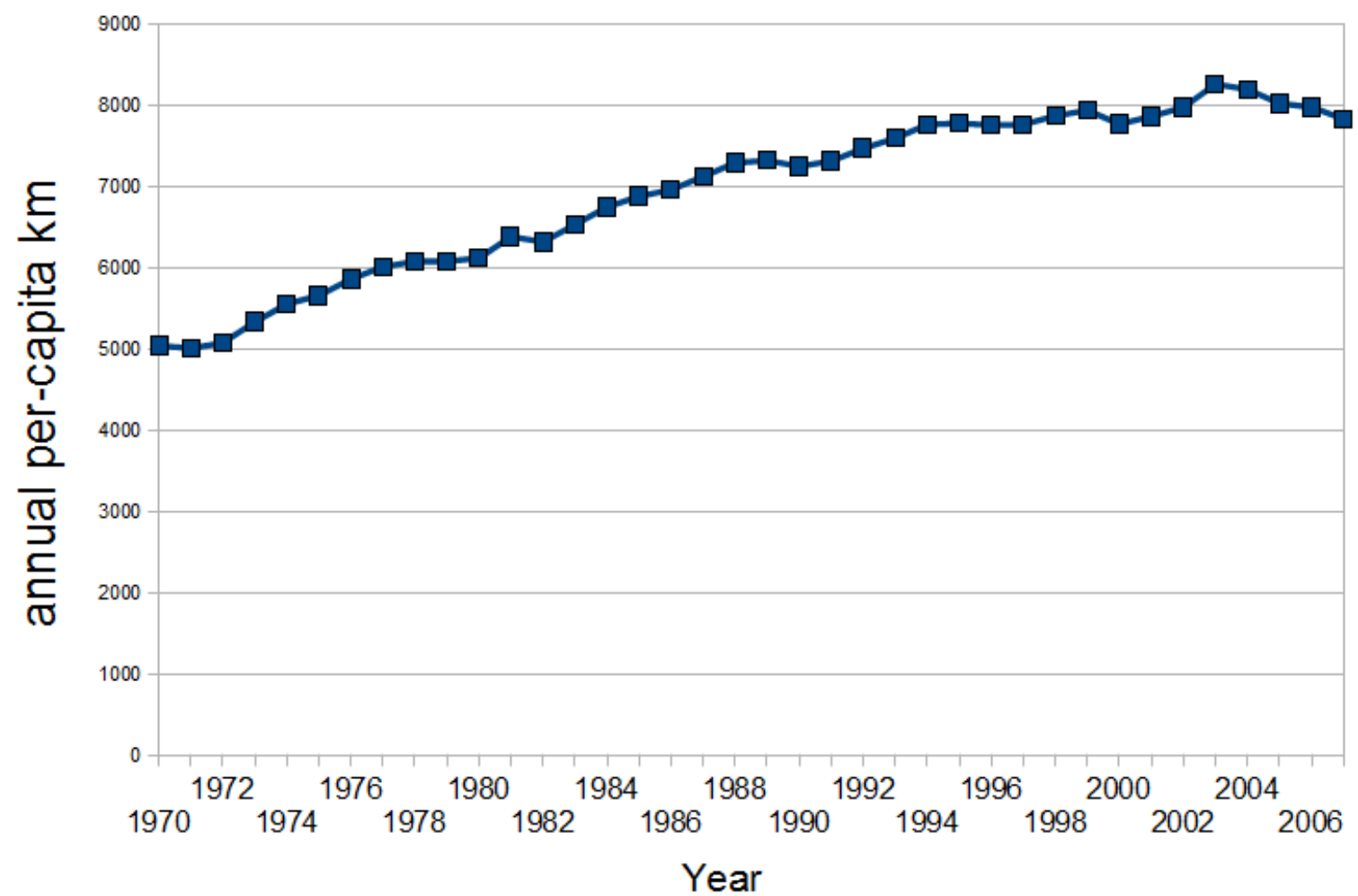

Figure 5. Per-capita VKT in Australia. Source: Author's calculations based on BITRE (2009, page 74), and ABS (2009b)

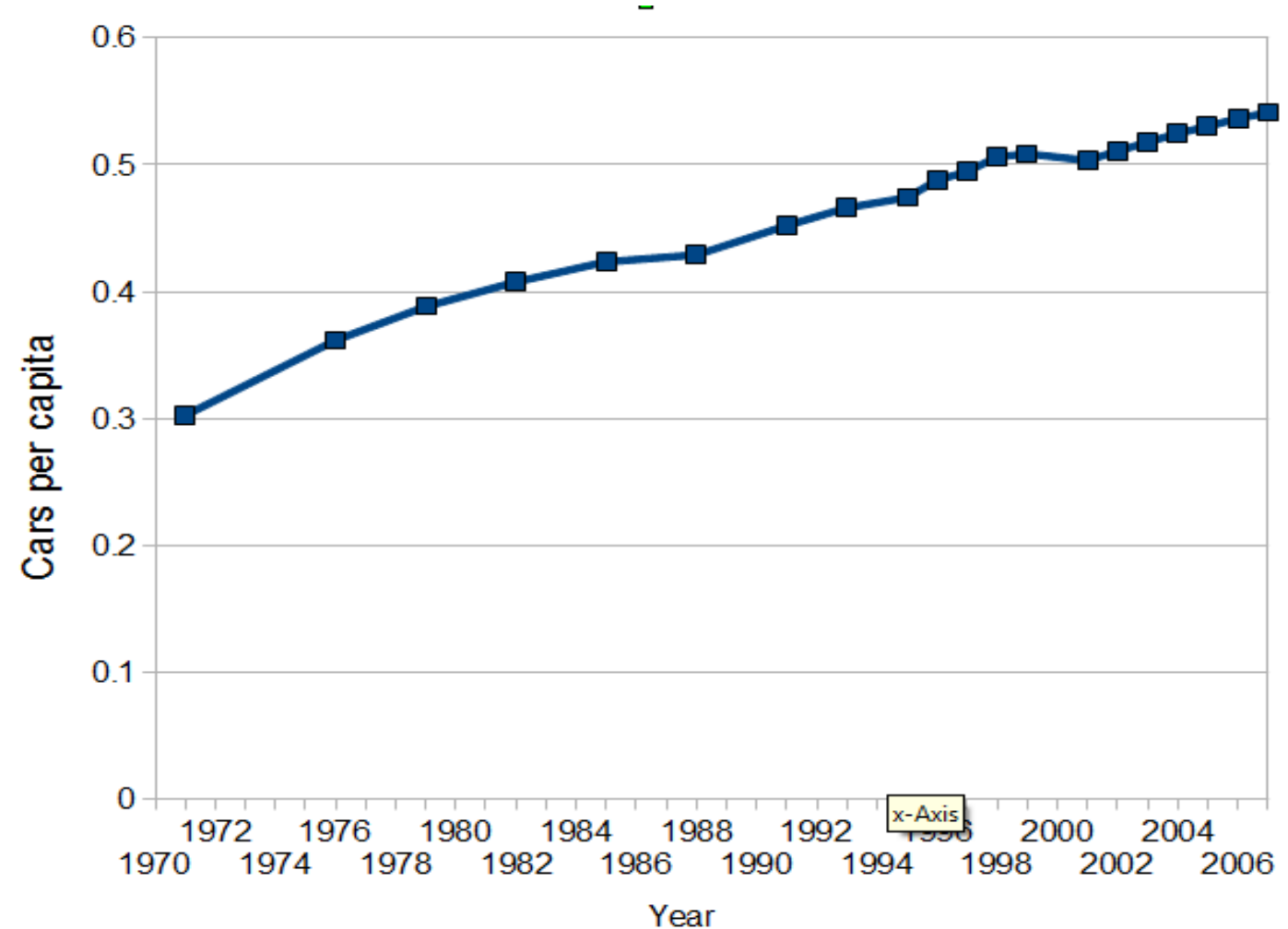

Figure 6. Per capita car ownership in Australia. Source: author's calculations from BITRE (2009, page 73 ), and ABS (2009b). 
On the aggregate figures, it thus appears that while increasing car ownership and VKT have historically been significant drivers of oil use in Australia, they are likely to play a lesser role in the future. More important than changes to per-capita car ownership and VKT levels will be changes in total population.

While aggregate statistics on per-capita VKT suggest that personal travel is plateauing, it is important to note that there are a number of underlying factors that are responsible for this plateauing besides the natural limits already mentioned (i.e. saturating ownership and traveltime constraints). For example, there has been less fringe expansion and more urban consolidation in Australian cities in the last three decades (see Randolph (2006)), and this would have played a part in curbing VKT-growth, as we know that the distance driven by outersuburban households is an order or magnitude more than the distance driven by innersuburban households (see Figure 7). Even after adjusting for household structure and income, equivalent outer-suburban households travel around two to three times the distance of their inner-suburban equivalents (Perkins 2002; Rickwood 2009). There are two interrelated reasons for this: public transport service is generally very poor, and activities are more spread out, making trips longer. There are between-city differences also, with Sydney having lower car-use than other Australian capitals even after controlling for other factors (see Rickwood and Glazebrook (2009)).

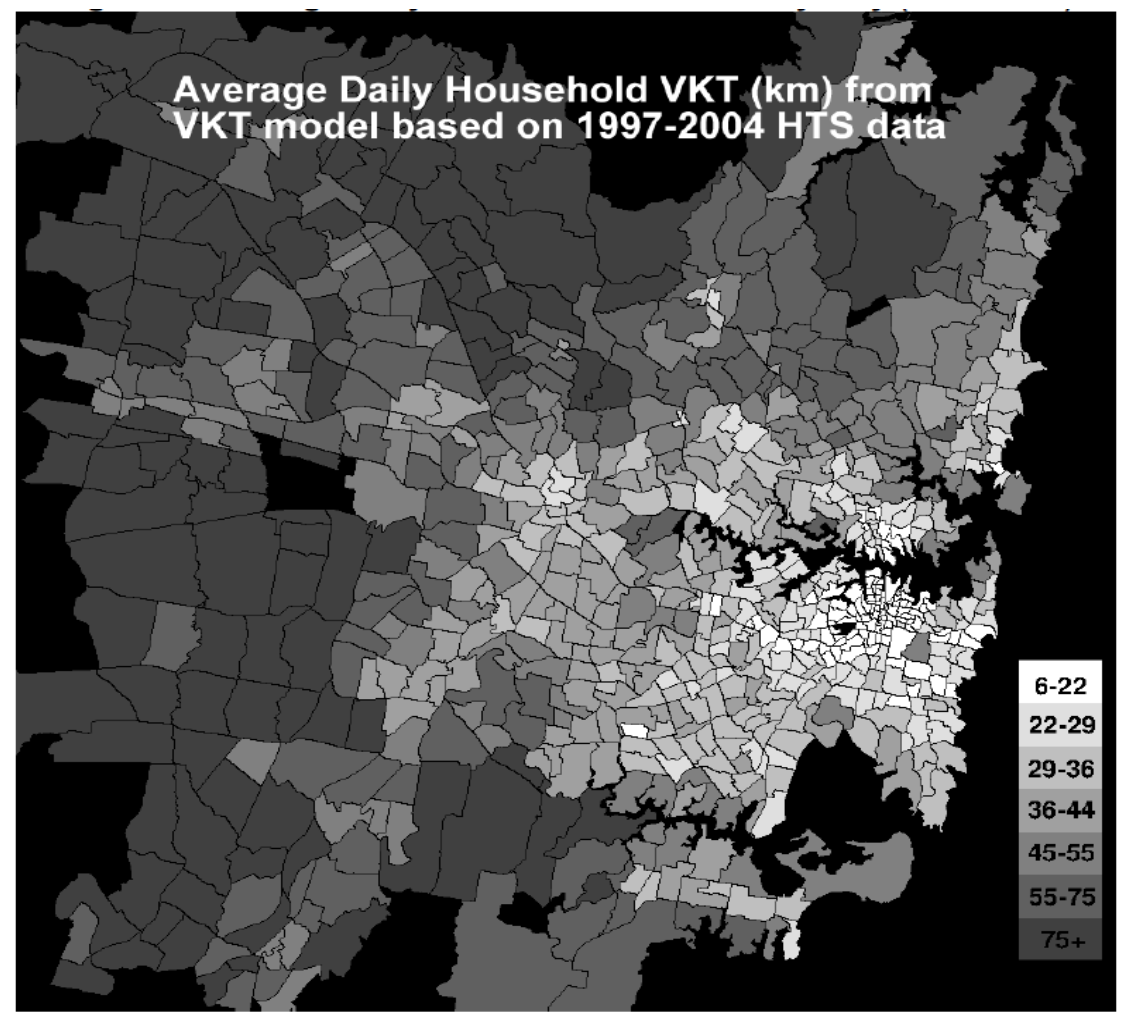

Fig 7: Daily vehicle kilometres per household by travel zone in Sydney. Source: author's calculations using VKT model adapted from data described in Corpuz et al. (2006).

Looking forward, all factors point to plateauing per-capita VKT even with stable petrol prices. There is even the possibility of a decline in per-capita VKT, given that congestion caused by a growing population may encourage some shift to public transport. The strength of this shift would of course be heavily influenced by the quality of public transport infrastructure and 
service provided, and the appropriateness of accompanying land-use planning. With plateauing per-capita VKT and modest improvements in fleet efficiency, fuel demand is likely to be increase at somewhat less than the population growth rate, most recently forecast to be $1.2 \%$ out to 2049 (Australian Treasury 2010). Given flat per-capita VKT and increasing fuel efficiency, we might reasonably expect total private passenger fuel consumption under 'business as usual' to increase at a rate below $1 \%$ per annum.

\section{Commercial trucking ( $20 \%$ of total oil)}

Summary: Fuel use largely driven by economic growth.

The quantity of fuel used for commercial trucking has grown more-or-less in-line with GDP over the last 20 years. The relationship is a little more complicated than this, because the volume of goods (i.e. tonne-kilometres) trucked has grown faster than GDP at $4.4 \%$ per annum (BITRE, 2009), but this has been offset by other factors such as improved fuel efficiency. The growth in tonne-kilometres has been driven by changes in patterns of inter-regional trade (which has increased over the past four decades), by changing goods-transport requirements (i.e. increased overnight trucking), and by logistics and warehousing (e.g. low-inventory 'just-intime' warehousing and distribution). It seems likely that under 'business as usual', trucking fuel consumption will be driven largely by economic growth.

\section{Aviation (13\% of total oil)}

Summary: Rapid growth expected to continue under 'business as usual', where incomes continue to rise and fuel costs do not increase substantially. Downside risks posed by poor economic conditions and/or significant increases in fuel costs are substantial.

The aviation sector has had the fastest growth in fuel consumption over the last 20 years, with fuel consumption growing at a faster rate than GDP. Fuel consumption grew at a compound annual rate of $3.97 \%$ between 1987-2007, but this understates the growth in air travel, because fuel efficiency has increased dramatically over the same period. The number of seat-kilometres flown has grown by $7.3 \%$ per year over the same period (BITRE 2009, page 93). Growth in air travel has been driven by both rising incomes and declining flight costs. Leisure air travel is a luxury good, and so demand grows faster than incomes as incomes rise. Thus, even if air-fares had remained constant over the last 20 years, we would have expected a significant increase in air travel. But in fact, air fares have fallen dramatically in real terms. Since 1993, for example, air-fares have fallen by $32 \%$ (BITRE 2009). The combination of declining real costs and increasing incomes has caused the air-transport sector to be the fastest growing transportation sector. If incomes continue to rise, and fuel prices remain near current levels in real terms, aviation is likely to see continued rapid growth. The aviation industry is, however, very sensitive to economic conditions, and the long-term outlook would be greatly altered by poor economic conditions and/or increasing fuel costs. These issues are explored further in Section 6.

\section{Other (32\% of total oil)}

Mining (8.5\%), chemicals \& lubricants (7.1\%), water transport (5\%), agriculture $(4.8 \%)$, rail (2\%), bus $(1 \%)$, other $(3.6 \%)$.

Summary: Continued growth in mining and water transport, driven by mining industry growth and international trade. Outlook for other sectors less clear. 
The end-uses making up the remaining $32 \%$ of oil consumption are too varied to cover in any detail in this article. Mining oil consumption (8.5\%) will be driven by growth (or otherwise) in the mining industry. Water transport (5\%) will be driven by growth in long-distance bulky goods transport (i.e. inter-national trade). The number of factors influencing oil use in the other sectors means that the outlook for those sectors is less clear.

\section{Oil and climate change}

Because climate change mitigation is receiving a lot of attention, it is common for oil consumption to be viewed through this lens. Given that transport makes up most oil consumption, and transport is an issue of particular interest and relevance to planners, it is natural enough for planning researchers and policy-makers to consider the greenhouse emissions attributable to transport. Transport-related energy consumption and related greenhouse emissions are significant, making up 14.7\% of Australia's total greenhouse emissions in 2009 (DCCEE 2010, page 3). This is lower than transport's share of total energy use (24\%) because oil is a less intensive greenhouse fuel than the other major fuels: coal and gas. Most urban transport energy is consumed in private passenger vehicles, and this is also the area that planners can have the most influence. The urban planning research on this matter is clear - fringe development results in high car ownership and use (Bento et al 2003; Ewing 2002; Rickwood et al. 2008), and development near well-connected employment and transport nodes results in lower car ownership and use ${ }^{1}$ (Rickwood and Glazebrook 2009). These findings are broadly acknowledged by policy-makers, with the importance of centres and corridors acknowledged in most major metropolitan planning documents. It remains to be seen how well (or whether) these plans are implemented.

The most important influence that climate change will have on the transport sector is that it will make a straightforward transition to coal and gas derived energy more difficult. If $\mathrm{CO}_{2}$ emissions were not an issue, it would be possible, over the long term, to reduce oil consumption by synthesising liquid fuels from coal or gas, or by moving to electric vehicles. Either of these options, however, would result in a significant increase in greenhouse emissions unless they were accompanied by other measures such as carbon sequestration or renewable electricity generation. In the following section, where I evaluate the ability of the transport sector to adapt to expensive oil, I will exclude adaptive options that have adverse consequences for $\mathrm{CO}_{2}$, as they will be untenable given any serious efforts to curb $\mathrm{CO}_{2}$ emissions. I will also not consider options that require the use of technologies that may be possible, but are not yet feasible or economic.

\section{The Transport Sector's ability to adapt to expensive oil}

Note: In this section, I will use estimates of price elasticity to assess the transport sector's likely response to increased oil prices. For the purposes of this paper it is not possible to either provide background information about this approach, or discuss possible alternate approaches. For a good general summary see Krugman \& Wells (2006, Chapter 5).

To understand how different transport modes might adjust to high oil prices, it is necessary to understand three things: how sensitive demand for those modes is (i.e. the price-elasticity of

1 I stress the 'well connected' because it is clear that access to a nearby centre alone is not a good indicator of general access to urban services. Access to a highly connected centre, however, is a good indicator (Rickwood and Glazebrook, 2009). 
demand); whether alternate fuels are available (fuel substitutes); and whether demand for travel by that mode may be substituted by some other mode of transport or some other technology (mode substitutes). Table 2 summarises information available on these three factors for different transport nodes. From this information, one can map out a conventional economic view of how oil price increases will affect the transport sector: the short-term response to a rise in oil prices is a large reduction in demand for leisure air travel, and a less marked reduction in business air-travel. Sustained high oil prices would see these demand reductions sustained over the longer term, and possibly strengthened slightly due to longerterm responses by businesses to substitute air-travel with videoconferencing or other collaborative technology. For private passenger vehicles (the largest single use), the short-term response is likely to be a modest decline in vehicle use. Longer term, this reduction in vehicle use will be accompanied by increased vehicle efficiency.

\begin{tabular}{|c|c|c|c|c|c|}
\hline & $\begin{array}{l}\text { elasticity (short- } \\
\text { run) }\end{array}$ & $\begin{array}{r}\text { elasticity } \\
\text { (long-run) }\end{array}$ & $\begin{array}{l}\text { Fuel } \\
\text { substitutes }\end{array}$ & $\begin{array}{l}\text { Other } \\
\text { substitutes }\end{array}$ & $\begin{array}{l}\text { Likely response to } \\
\text { high oil prices }\end{array}$ \\
\hline $\begin{array}{l}\text { Business air } \\
\text { travel }\end{array}$ & $\begin{array}{l}\text {-1.1 (Nairn and } \\
\text { Hooper, 1992, } \\
\text { p55) }\end{array}$ & $\begin{array}{l}\text { Unclear. Likely } \\
\text { somewhat } \\
\text { (but not } \\
\text { greatly) higher } \\
\text { than short- } \\
\text { run. }\end{array}$ & None & $\begin{array}{l}\text { Video- } \\
\text { conferencing }\end{array}$ & $\begin{array}{l}\text { Demand reduction. } \\
\text { Longer-term -- } \\
\text { reorganization of } \\
\text { business processes } \\
\text { for more video- } \\
\text { conferencing. }\end{array}$ \\
\hline $\begin{array}{l}\text { Leisure air } \\
\text { travel }\end{array}$ & $\begin{array}{l}-3.2 \text { (Lubulwa, } \\
1986, \text { p208) } \\
-2.3 \text { (Nairn and } \\
\text { Hooper, 1992, } \\
\text { p55) }\end{array}$ & $\begin{array}{l}\text { Unclear. Likely } \\
\text { similar to } \\
\text { short run }\end{array}$ & None & Domestic holidays & Demand reduction. \\
\hline $\begin{array}{l}\text { Private } \\
\text { passenger } \\
\text { vehicles }\end{array}$ & $\begin{array}{l}-0.25 \text { (Goodwin et } \\
\text { al., 2004) } \\
-0.25 \text { (Graham } \\
\text { and Glaister, } \\
2004 \text { ) } \\
-0.15 \text { (Gargett } \\
\text { and Hossain, } \\
\text { 2008) }\end{array}$ & $\begin{array}{l}-0.64 \\
\text { (Goodwin et } \\
\text { al., 2004) } \\
-0.77 \text { (Graham } \\
\text { and Glaister, } \\
2004 \text { ) } \\
-0.4 \text { (Gargett } \\
\text { and Hossain, } \\
2008 \text { ) } \\
\end{array}$ & $\begin{array}{l} \\
\text { Other liquid } \\
\text { fuels } \\
\text { Electricity } \\
\text { Hydrogen }\end{array}$ & Public transport & $\begin{array}{l}\text { Mixed. Short term } \\
\text { some demand } \\
\text { reduction, some } \\
\text { mode switch. } \\
\\
\text { Longer term unclear } \\
\text { except for lower } \\
\text { vehicle fuel } \\
\text { consumption. }\end{array}$ \\
\hline $\begin{array}{l}\text { Commercial } \\
\text { trucking }\end{array}$ & $\begin{array}{l}\text { Depends on good } \\
\text { being trucked. } \\
-7.42 \text { to } 1.72 \\
\text { (Graham and } \\
\text { Glaister, } 2004) \text { - } \\
\text { international } \\
\text { mean }-1.07 \text {, std. } \\
\text { dev. } 0.84 \text { ) }\end{array}$ & $\begin{array}{l}\text { Unclear, but } \\
\text { higher than } \\
\text { short-run. }\end{array}$ & $\begin{array}{l}\text { Other liquid } \\
\text { fuels }\end{array}$ & $\begin{array}{l}\text { Rail freight } \\
\text { (imperfect) }\end{array}$ & $\begin{array}{l}\text { Reduced demand } \\
\text { for a few goods (i.e. } \\
\text { price-elastic low } \\
\text { value, bulky goods) } \\
\text { Some transfer to rail } \\
\text { and sea where } \\
\text { possible (i.e. non- } \\
\text { perishables). }\end{array}$ \\
\hline
\end{tabular}

Table 2. Price elasticity and substitution information for major transport end-uses.

To make the data in Table 2 a little more concrete, let us see what would happen if fuel prices were to increase by two thirds and be sustained at this level (in real terms) for several years. At 
this level, the elasticities in Table 2 suggest that leisure air travel in and from Australia would decline by around $50 \%^{2}$, and business air travel would decline by perhaps a quarter ${ }^{3}$. Using the elasticities reported in Goodwin et al. (2004), we would expect private vehicle fuel use to decline in the short term by a quarter - about half of which takes place through reductions in discretionary travel, and the other half through other measures such as driving more fuel efficient vehicles (i.e. multi-car families prioritizing use of the more fuel efficient vehicle). In the longer term (3-5 years), we would expect around a 64\% reduction in automotive fuel use (Goodwin et al., 2004), being made up of $~ 30 \%$ reduction in actual travel and a $50 \%$ improvement in vehicle fleet efficiency (whether through technology or other means such as car pooling). If a $50 \%$ improvement in fleet efficiency in 3-5 years strikes you as unrealistic, you are not alone, and this highlights the difficulty of relying on the standard elasticity data reported in the transport economics literature. We cannot reasonably extrapolate the information in the transport economics literature to a future with \$US 150-200/barrel oil because price elasticity changes with price, and we have very little recent information about price elasticities above \$US 75 per barrel. The situation is even worse for long-run elasticities, because the real price of oil (in 2008 dollars) has been above \$US 60/barrel for a sustained period only once before - from 1979 to 1983. In short, we are entering uncharted territories, and the existing information we have on price (and income) elasticities are at best a useful rough indicator.

Although the information shown in Table 2 will not give an accurate quantitative guide to how the different transport sectors would adjust to high oil prices, using the information within it we can, with some confidence, make the following predictions:

Car-based personal transport: There is some limited capacity to reduce demand by eliminating discretionary travel, but this is easily overestimated. Per-capita VKT was $35-40 \%$ lower in the 1970's (BITRE 2009), and given that this increase has been driven partly by society wide changes that cannot be easily undone (such as the move to double-income families), it may seem unrealistic to consider a return to that level of car-use possible. However, given that existing observed variations in city spatial structure and public transport networks have a large ( 20-25\%) independent effect on per-capita VKT (Bento et al. 2003; Ewing et al. 2002; Glaeser and Kahn 2008), it is not unreasonable to think that, over the long-term at least, changes in spatial structure coupled with complementary changes to transport infrastructure, networks, and planning could achieve substantial savings. In an Australian context, detailed modelling of land-use planning scenarios has indicated that residential land-use planning policies alone can result in a $10 \%$ reduction in per-capita private VKT over the long term, even assuming continued reliance on private motor vehicles for mobility, with limited investment in public transport (Rickwood 2009). Public transport is a potential substitute for car travel, but currently it is, for most Australians, a poor one. This need not remain the case. A renewed focus on public transport infrastructure provision and (perhaps more importantly) network planning would make public transport a better substitute for car travel.

Improved vehicle efficiency could also dramatically reduce oil consumption, with fleet-wide reductions in fuel use approaching $50 \%$ achievable with currently available vehicle technology. However, the length of time required to replace the vehicle fleet ( 20 years) means that it is

2 This is calculated based on an elasticity of -2.75 (the mean of the two values given in Table 2), a $66 \%$ increase in fuel price, and assumed fuel costs comprising $25 \%$ of total fare costs.

3 Same assumptions as for leisure travel, but with an elasticity of -1.1, as reported in Nairn and Hooper (1992). 
important that we start making changes to our fleet immediately. Plug-in electric vehicles could also play a role provided that the electricity required came from renewable.

To cope with higher oil prices, some moderate reduction in car travel (at least $10 \%$ ) could be achieved through demand reduction alone with limited impact on economic and/or social wellbeing. As explained above, a further $20-30 \%$ reduction in fuel use could be achieved through better land-use and transport planning that would both reduce the need for some travel, and allow other travel to take place on public transport. Combined with the fleet efficiency improvements of up to $50 \%$ already mentioned, these measures would result in per-capita private vehicle fuel use decreasing by two-thirds. See Glazebrook and Rickwood (2008) for a more detailed discussion.

Commercial trucking: At first glance, it might seem that an increase in fuel costs would pose a serious problem for non-bulky goods transport, because there are no fuel substitutes, there is no scope for transitioning to electric or hybrid vehicles, and because rail cannot currently compete for goods that require timely delivery. However, fuel costs are only a few percent of final goods costs (Gargett and Hossain 2008, page 3), so even a very large increase in fuel costs would result in relatively small flow-on costs to delivered goods. For goods that require fast end-to-end delivery there is no clear substitute to trucking, and extra fuel costs will simply be passed on with little change in trucking volumes and only small flow-on cost pressures on delivered goods. Thus, while there is little scope for adaptation to high fuel prices, there is little need to adapt, as costs can be passed on to freight customers and from there to consumers. As a consequence, tonne-kilometres and consequent fuel use could continue to grow even in the face of increases in fuel costs. One substitution possibility not covered here (but discussed in detail in Glazebrook (2009)) is transporting trucks via rail (i.e. on flatbed rail carriages), with the trucks driving on/off at rail end-points. This could save a significant quantity of fuel, but would require better freight rail management $\&$ logistics, because to short-haul commercial trucking often requires fast delivery.

Aviation: The aviation sector has very limited adaptive potential, as there are no clear non-oil based substitutes for jet-fuel, and demand is sensitive to price. There is also limited potential for demand to be substituted through video-collaboration, virtual meetings, or other technologies. Thus, both airlines and airline customers will be greatly affected by an increase in oil prices, over both short and long terms.

\section{Summary \& policy implications}

From the preceding analysis, we can see that oil use is concentrated in the transport sector, and there are no short term substitutes for oil-derived liquid fuels that can be widely adopted. These observations mean that besides large reductions in transport demand, there are few obvious short-term adaptive options for the transport sector. Things are better, but not by much, over the longer term. Over the longer term, there could be some partial transitioning to alternate fuels (i.e. coal to liquid-fuel, biofuels), but there are significant environmental or economic issues associated with large-scale substitution of petroleum-derived fuel with alternate fuels, so fuel-switching cannot be a long term solution by itself.

Recommendation: Oil will not be replaced by other liquid fuels. Reducing oil consumption will require measures other than simple fuel-switching, and planners need to prepare for this. 
Before attempting to distil further policy implications for planners from the material presented earlier, it is worthwhile taking a step back to consider how one should frame the the liquid fuels 'problem' caused by peak oil. The simplest approach one can take is to estimate what is likely to happen, and then put in place a planning strategy to copy with the envisaged future. This approach is common in many planning documents, and has the benefit of being simple and comprehensible. These are valuable attributes, but such an approach is not well suited to situations where the future is uncertain, and where unlikely events have very high associated costs. For example, most will concede that there is great uncertainly about the future price of oil, and of the way in which the transport sector in particular, and economy more generally, would respond to higher oil prices. But uncertainty makes the case for preparatory action stronger because the economic and social costs of high oil prices are not linear: most people and most businesses can dispense with some discretionary travel with little loss and make other adjustments with minor inconvenience, but when petrol rises beyond a certain price it begins to disrupt important social and business travel - interfering with the economic and social functioning of our settlements. When viewed this way, the case for early action is much stronger, because the costs of particular measures are not balanced merely against the likely benefits of those measures, but also the unlikely benefits - the 'adaptive insurance' that those measures provide against unlikely, but costly, futures.

Recommendation: Planners should adopt a risk-management approach to planning for peak oil. This is not a recommendation to undertake mitigatory or adaptive policy responses at any cost. Rather, it is a recommendation that the costs incurred in preparing for high oil prices (through, for example, investment in public transport) be balanced against the future risk-weighted costs of dealing with high oil prices.

Taking this recommendation on board, what then does the material presented in Sections 1 through 6 tell us? Primarily, it tells us that aviation has very little adaptive potential, and that unless we dramatically increase rail's share of short-haul commercial freight, large reductions in oil use are unlikely to come from commercial trucking. Price pressures will force private motorists to reduce their fuel usage first. Luckily, this is an area where there are viable strategies to reduce oil use. It is also an area that planners have direct influence over.

Recommendation: Compared to the other transport sectors, fuel consumed by private vehicles is more easily reduced. It is this area that planners should focus on.

And how might planners go about this? There are three paths, all of which can be followed simultaneously. Firstly, a halving of fuel use is achievable simply by switching to smaller, more fuel efficient passenger vehicles. However, based on recent scrappage rates (ABS 2007), it would take around two decades to replace the existing vehicle fleet. This could be accelerated somewhat with 'cash-for-clunkers' style programs, but would still take many years. Since transitioning to a more efficient passenger fleet has few downsides, and many advantages quite apart from reducing oil dependence, this transition should be pursued with vigour now. If the standard policy approaches to achieving this transition (i.e. fuel efficiency standards, fuel taxes, fuel-economy based registration costs) are unavailable, planners can resort to less ideal measures more directly within their control, such as parking controls or differentiated parking charges based on vehicle type. Secondly, planners should prepare for the possibility that public transport will need to provide a viable substitute for many trips currently taken by car, rather than a means of providing peak-capacity to get people to and from work. This requires comprehensive transport networks covering our cities, rather than the predominantly radial 
systems we currently have (Mees, 2009). Thirdly, and finally, land-use and transport planning can, over the long term, both reduce the need for motorized travel and increase mode shift to public transport.

Recommendation: Vehicle efficiency, improved public transport networks, and integrated landuse/transport planning can all be pursued together, and together can achieve substantial reductions in oil use. Combined, these actions could result in per-capita savings approaching two thirds of current private-vehicle consumption (see Section 6).

The responses discussed above are all long-term strategies. Since the vehicle fleet cannot be changed in the short term, and large-scale expansion of public transport networks (even using only buses) would still take years, there is a need for planners to prepare separate short-term plans to deal with sudden spikes in oil price. If oil were to hit \$US 250 per barrel (for whatever reason), it would cause great disruption to large number of Australians who rely on the car for travel. It is therefore important that emergency transport plans be ready that could be put in place quickly to ameliorate the impact. These plans could be as simple as identifying 'emergency' bus lanes and planning to run emergency bus services to areas identified as being most sensitive to petrol price increases. There has already been some analysis of oilvulnerability in Australia which planners can draw on (Dodson and Sipe 2008).

Recommendation: Planners should identify households and businesses most vulnerable to oil price shocks, and prepare quickly implementable emergency adaptation plans to ameliorate the impact on these households and businesses.

\section{References}

ABARE Economics (2009). Energy Update. ABARE Economics.

ABS (2007). Motor Vehicle Census, Australia. Catalogue Number 9309.0.

ABS (2009a). Australian Historical Population Statistics 2008. Australian Bureau of Statistics. Catalogue number 3105.0.65.001.

ABS (2009b). Population by Age and Sex, Australian States and Territories. Australian Bureau of Statistics. Catalogue number 3201.0

Australian Treasury (2010). Australia to 2050: future challenges. Australian Treasury.

Bento, A. M., Cropper, M. L., Mobarak, A. M., and Vinha, K. (2003). The impact of urban spatial structure on travel demand in the United States. Technical Report 3007, World Bank.

BITRE (2009). Australian Transport Statistics. Bureau of Infrastructure, Transport and Regional Economics. Corpuz, G., McCabe, M., and Ryszawa, K. (2006). The Development of a Sydney VKT Regression Model. 29th Australasian Transport Research Forum.

DCCEE (2010). National Greenhouse Gas Inventory 2008. Department of Climate Change and Energy Efficiency.

Dodson, J. and Sipe, N. (2008). Shocking the Suburbs: urban location, homeownership and oil vulnerability in the Australian city. Housing Studies, 23(3):377-401.

Ewing, R., Cervero, R., Nelson, D., and Niles, J. (2001). Travel and the built environment: A synthesis. Transportation Research Record, 1780:87-114. 
Ewing, R., Pendall, R., and Chen, D. (2002). Measuring Sprawl and its Impact. Smart Growth America, Washington, DC.

Gargett, D. and Hossain, A. (2008). BITRE Briefing: How do fuel use and emissions repond to price changes? Bureau of Infrastructure, Transport and Regional Economics.

Glaeser, E. L. and Kahn, M. E. (2008). The greenness of cities: carbon dioxide emissions and urban development. NBER working papers, Working paper 14238.

Glazebrook, G. (2009). Railtruck: An intermodal freight solution for the Sydney-Melbourne and other short-haul freight corridors. Technical report, University of Technology Sydney.

Glazebrook, G., and Rickwood, P. (2008). Options for Reducing Transport Fuel Consumption and Greenhouse Emissions for Sydney. Built Environment, 34(3\}:349-363.

Goodwin, P., Dargay, J., and Hanly, M. (2004). Elasticities of road traffic and fuel consumption with respect to price and income: A review. Transport Reviews, 24(3):275-292.

Hirsch, R., Bezdek, R., and Wendling, R. (2005). Peaking of world oil production. US Department of Energy. Krugman, P. and Wells, R. (2006). Economics. Worth Publishers, New York, 2nd edition.

Lubulwa, A. S. G. (1986). Brandow demand functions for Australian long distance travel. In 11th Australian Transport Research Forum.

Mees, P. (2009). Transport for Suburbia: Beyond the Automobile Age. Earthscan.

Nairn, R. J. and Hooper, P. (1992). Tourism related movement study: final report. NSW Roads and Traffic Authority, Sydney, Australia.

Office of Highway Policy Information (2010). Traffic Volume Trends. US Department of Transportation.

Perkins, A. (2002). The influence of urban form on life cycle transport and housing energy and greenhouse gas emissions. PhD thesis, University of South Australia, Adelaide.

Randolph, B. (2006). Delivering the Compact City in Australia: Current trends and future implications. City Futures Research Centre Research Report Number 6.

Rickwood, P. (2009). The Impact of Physical Planning Policy on Household Energy Use and Greenhouse Emissions. PhD thesis, University of Technology, Sydney, Broadway, Sydney.

Rickwood, P. and Glazebrook, G. (2009). Urban structure and commuting in Australian cities. Urban Policy and Research, 27(2):171-188.

Rickwood, P., Glazebrook, G., and Searle, G. (2008). Urban structure and energy - a review. Urban Policy and Research, 26(1):57-81. 